\title{
Patterns of Iron Stain on Gelam Wood (Melaleuca cajuputi Powell)
}

\author{
Windy Agustiana Hayati ${ }^{1}$ Erwin ${ }^{1}$ Nani Husien ${ }^{1}$ Sri Wahyuni ${ }^{1}$ Isna Yuniar Wardhani ${ }^{1}$ \\ Agus Sulistyo Budi ${ }^{1, *}$ \\ ${ }^{1}$ Faculty of Forestry, Mulawarman University Jl. Penajam, Samarinda East Kalimantan Indonesia \\ *Corresponding author. Email: asulistyob@gmail.com
}

\begin{abstract}
Gelam wood is a tough wood that is often used to support building structures; usually, it was nailed to merge it each other which the nailing causes injury to the wood. The purpose of this research is to determine the patterns of distribution of iron stain in gelam wood. The wood's observation macroscopical is carried out by nailed eye to know the iron stain pattern in the transverse, tangential and radial section of the wood. The research measured the distribution of iron stain caused by nails and observed the other organism's presence. The observation found that there were iron stains around the nail scars, which to longitudinal and radial section was more intensive than tangential directions. There are no other organisms around the nail zone in macroscopical observation, and the other side of the wood was found. It can be concluded that the distribution of scars more visible in the longitudinal direction than the others due to the parallel of the cell length. While in the radial direction, the iron stains follow the length of the nail and in the tangential direction is less intensive because it inhibits the wall of the fibre cell and the less of the pith as the entrance of the stain.
\end{abstract}

Keywords: Gelam, Wood, Discoloration, Iron stain

\section{INTRODUCTION}

Indonesia has a wide range of plants in each region, with 4,000 trees potentially used for building construction and about 400 species with economic value and 260 species classified as trading timber [1].

There are varieties of properties from each type of wood, including physical, mechanical, chemical and anatomical properties. These properties can be used as a requirement for the use of certain woods, e.g., construction, railway bearings, musical instruments, shipping, furniture and many others.

Gelam tree/swamp tea-tree (Melaleuca cajuputi Powell) belongs to the Myrtaceae family, mostly found in the islands of Sumatra, Kalimantan, Sulawesi, Maluku and Papua [2]. This wood is often used as a building buffer, which is why this tree is called solid wood. In addition, the wood is often used as wood construction, firewood, briquettes and sawn timber. The local community has been using the cajuput tree as a piling with decades of life usage, supported by its straight-tipped branch stems [3] and rapid growth of gel with $1-1.5 \mathrm{~cm}$ per year increments [4] also, the price of gelam wood is cheap.
When it used as a steger it often connected with nails; this causes discolouration on the wood. The purpose of this study was to determine the pattern of discolouration caused by nails from the tangential, radial and longitudinal directions of wood.

\section{METHOD AND MATERIALS}

\subsection{Materials}

Gelam (Melaleuca cajuputi Powell) is used as material for the research. The diameter is $\pm 7 \mathrm{~cm}$, and the length is $\pm 3 \mathrm{~m}$; the wood has been used as a buffer and has been injured with nails. Of the three different logs, it separated into ten wood samples that have nail wounds.

\subsection{Wood Discolouration}

Observation of wood discolouration due to nail wounds is done macroscopically by observing from three wood directions: longitudinal, radial, and tangential. Observations were made by direct observation while discolouration presentation was 
measured using a ruler and shooting was done with the Canon EOS 1100D Camera.
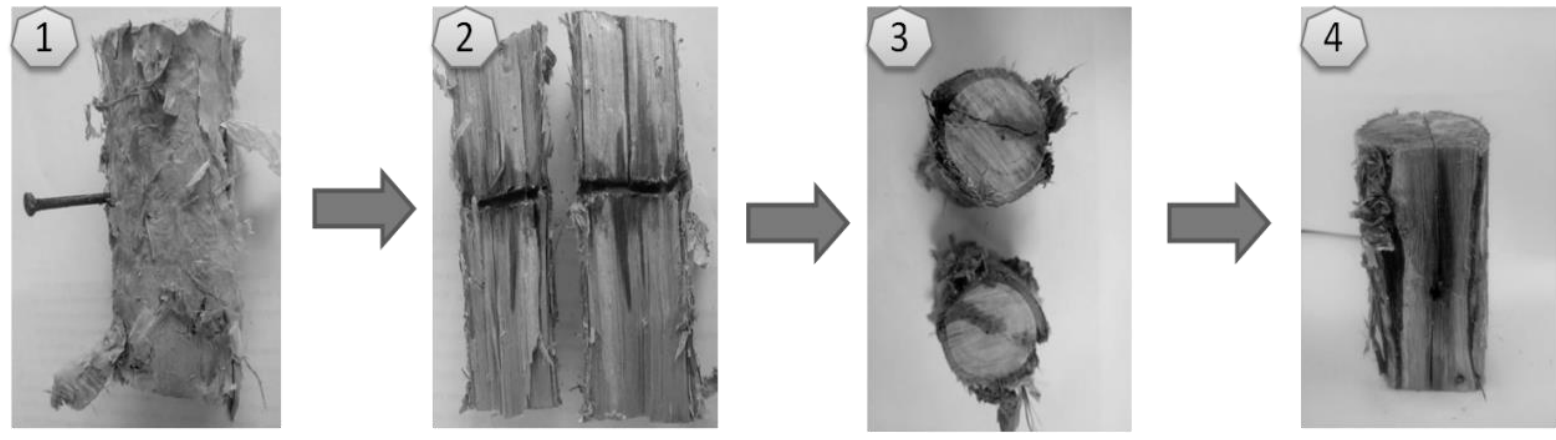

Figure 1 The process of making the samples: (1) The woods which have nail wounds are separated from whole wood with $15 \mathrm{~cm}$ long (2) The woods which have separated then cut in half in the longitudinal direction (3) and then cut in the radial direction (4) also cut in the tangential direction

\section{RESULT AND DISCUSSION}

Discolouration is the change of wood's colour that deviates from the natural colour of the wood. This often happens to wood but does not always reduce the value of the wood itself. Sometimes, discolouration increases wood's sale value, such as giving colour to the final product made from wood [5]. There are several examples of discolouration cases in wood with different causes, such as discolouration in the living tree, discolouration during storage, discolouration during clean drying and chemical reaction (Figure 2) [6].

Iron stains are metal stains that occur because the reaction of iron elements with phenolic chemicals found
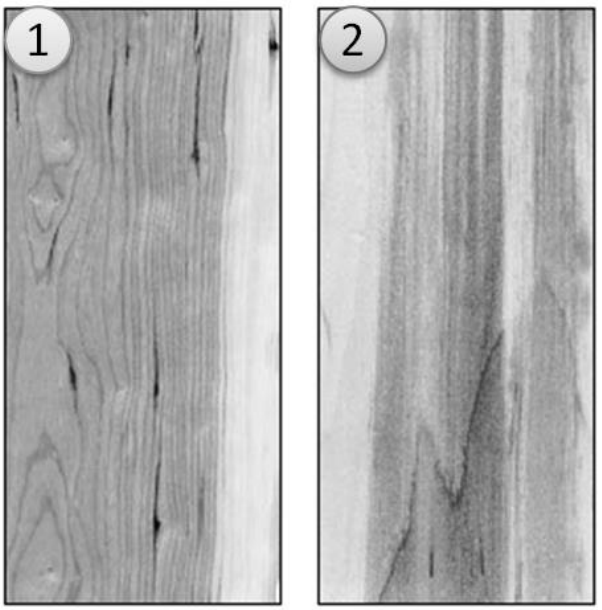

in wood and form black iron tannates [7], it is known that gelam wood contains chemical compounds such as holocellulose, lignin and pentosan [8]. In addition water can also help in the reaction process between iron and wood [5], this is in sync with the use of gelam as a steger used outdoors so that the wood is exposed to sunlight and exposed to rainwater.

The observation found that there were iron stains around the nail scars, discolouration that happened in the wood is black. The spreading of iron stains in the longitudinal direction was more intensive than the tangential direction.

Figure 2 Example of discolouration with different cases: (1) Gums in Black Cherry (2) Staining of Hard maple (3) Oxidative staining of Frame (4) Iron-tanning stain of Oak 
Table 1. Distribution of Iron Stain

\begin{tabular}{lcc}
\hline Sample & Longitudinal direction $(\mathbf{c m})$ & $\begin{array}{c}\text { Tangential direction } \\
(\mathbf{c m})\end{array}$ \\
\hline Sample 1.1 & 5,3 & 0,5 \\
Sample 1.2 & 4,7 & 0,5 \\
Sample 1.3 & 5,3 & 0,5 \\
Sample 1.4 & 1,9 & 0,9 \\
Sample 2.1 & 4,2 & 0,6 \\
Sample 2.2 & 3,7 & 0,6 \\
Sample 2.3 & 2,6 & 0,6 \\
Sample 2.4 & 5 & 0,9 \\
Sample 2.5 & 2,5 & 0,6 \\
Sample 3.1 & 3 & 1,1 \\
& $(1,9)-3,82-(5,3)$ & $(0,5)-0,68-(1,1)$ \\
\hline
\end{tabular}

The wood's longitudinal direction shows the average spread of iron stains is $3,82 \mathrm{~cm}$, with the shortest spread of iron stains $1,9 \mathrm{~cm}$ long, and the longest is $5,3 \mathrm{~cm}$ long (Table 1). Long cells play a role in the spread of iron stains, lumina cells, fibre cells, and vessel cells. This happens like water and nutrients that move vertically through fibres, functioning as supporting facilities or transportation to all tree parts [9]. While in the tangential direction of the wood, it looks shorter and narrower. The average spread is $0.68 \mathrm{~cm}$, with the shortest spread of $0.5 \mathrm{~cm}$ and the longest spread of 1.1 $\mathrm{cm}$ long (Table 1). This is because the fluid must pass through the cell wall of wood cells such as pore and fibre cells. The second cell wall in wood has compositions such as cellulose, hemicellulose and lignin, which meet its layer that can inhibit the spread of iron stains [10].

As seen in Figure 3 and Figure 4, differences in patterns in the spreading iron stains are very significant. Table 1 the average measurement of the spread of iron stains. The spreading speed of iron stains in the longitudinal direction is $5 \mathrm{x}$ faster than iron stains in the tangential direction.

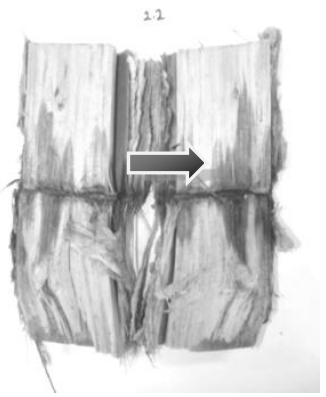

Figure 3 The wood sample has cut in half in the longitudinal direction

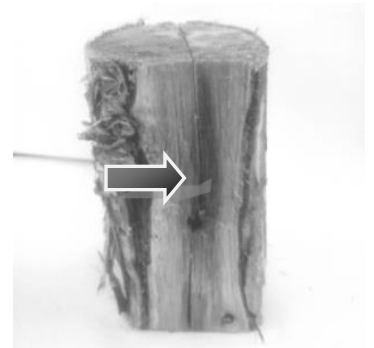

Figure 4 The wood sample has cut in the tangential direction

\section{CONCLUSIONS}

Based on the observations, it can be concluded that:

1. Discolouration causes nail wounds on wood that is mostly black.

2. The observation of discolouration on a macroscopical is found around the nail scars.

3. The spreading of iron stains in the longitudinal direction was more intensive than the tangential and radial direction.

4. The spreading speed of iron stains in the longitudinal direction is $5 \mathrm{x}$ faster than iron stains in the tangential direction.

\section{ACKNOWLEDGMENTS}

The authors would like to thanks M. Said for helping in collecting and processing the sample.

\section{REFERENCES}

[1] E.A. Wheeler, P. Gasson, P. Bass, List of microscopic features for hardwood identification, IAWA Bull n.s, 10, 1989, p. 219.

[2] Khairil, Klasifikasi kode mutu kayu, INERSIA, Provinsi Sulawesi Selatan, Ujung Pandang, XIII(1), 2017, pp. 41-53. 
[3] W. Supriyati, T.A. Prayitno, Soemardi, S.N. Marsoem, Heartwood proportion and physicalmechanical properties of three diameter class of gelam wood (Melaleuca sp.) from central kalimantan, J. Ilmu dan Teknologi Kayu Tropis, 12(1), 2014, pp. 56-64.

[4] D. Rachmanady, D. Lazuardi, P.T. Agustinus, Teknik Persemaian dan Informasi Benih Gelam, Pusat Penelitian dan Pengembangan Bioteknologi dan Pemuliaan Tanaman Hutan, Pusat Penelitian dan Pengembangan Bioteknologi dan Pemuliaan Tanaman Hutan, Yogyakarta, 2004.

[5] T. Shupe, S. Lebow, D. Ring, Causes and control of wood decay, degradation and stain, Miscellaneous Publication, Lousiana State, Rev 6/08, 2008, pp 26.

[6] G. Koch, Discoloration of wood in the living tree and during processing, Conference COST E53 The Netherlands, 2008.

[7] A. Uzunovic, T. Byrne, M. Gignac, D.Q. Yang, Wood discoloration \& their prevention with an emphasis on bluestain, Natural Resources Canada, Canada, 11, 2008, p. 48.

[8] M. Muslich, M. Wardani, T. Kalima, S. Rulliaty, R. Damayanti, N. Hadjib, S. Suprapti, M.I. Iskandar, Abdurachman, E. Basri, I. Heriansyah, H.L. Tata, Atlas Kayu Indonesia Pusat Penelitian dan Pengembangan Keteknikan Kehutanan dan Pengolahan Hasil Hutan, Bogor, IV, 2013.

[9] G. Thomasson, J. Capizzi, F. Dost, J. Morrel, D. Miller, Wood preservation and wood product treatment, Oregon State University, Corvallis, 2015.

[10] R. Zong, Z.H. Ye, Second cell walls: biosynthesis, patterned deposition and transcriptional regulation, Plant \& Cell Physiology, 56(2), 2014, pp. 195-214. 